ppi $201502 Z U 4645$

Esta publicación científica en formato digital es continuidad de la revista impresa ISSN-Versión Impresa 0798-1406 / ISSN-Versión on line 2542-3185Depósito legal pp $197402 Z$ U34
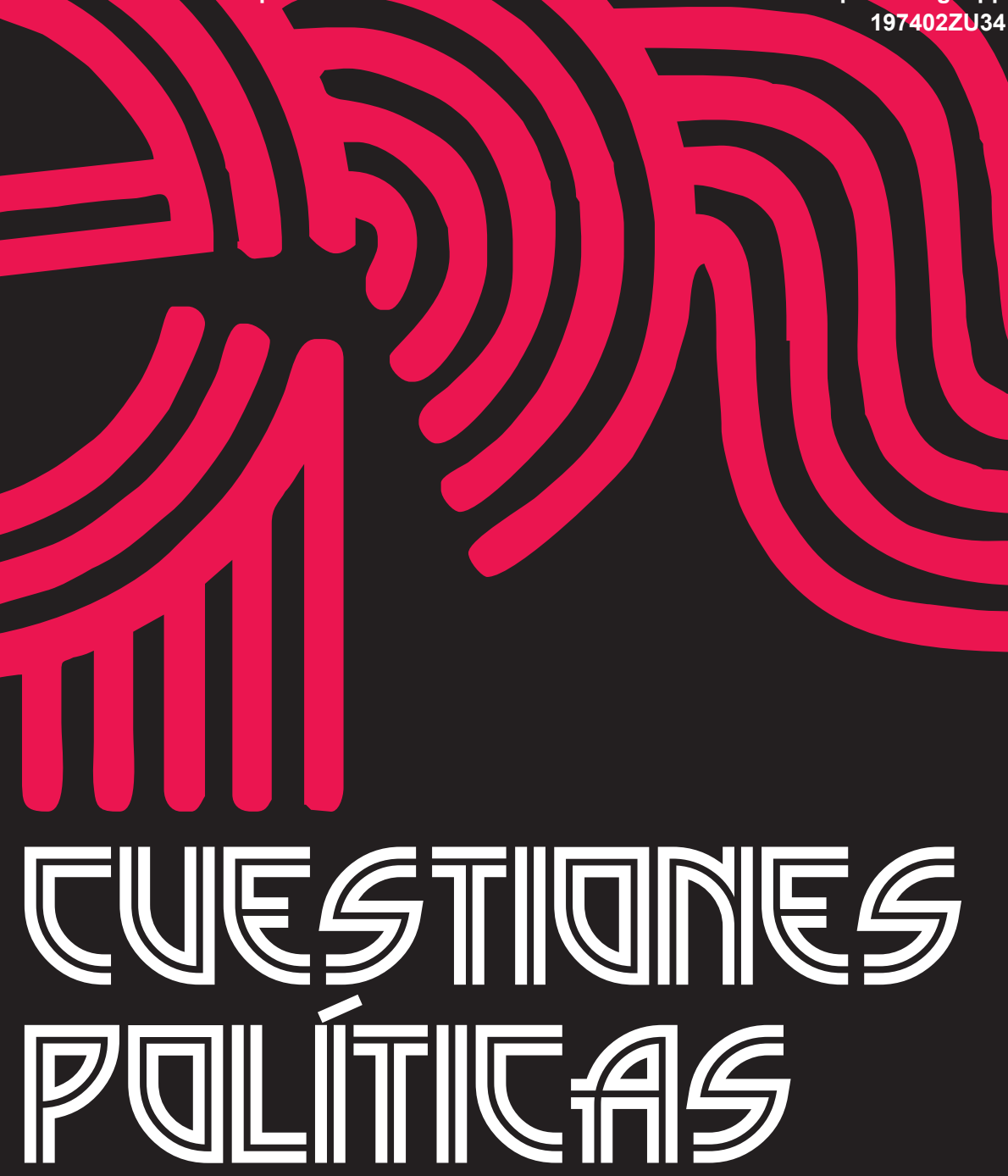

Instituto de Estudios Políticos y Derecho Público "Dr. Humberto J. La Roche" de la Facultad de Ciencias Jurídicas y Políticas de la Universidad del Zulia Maracaibo, Venezuela
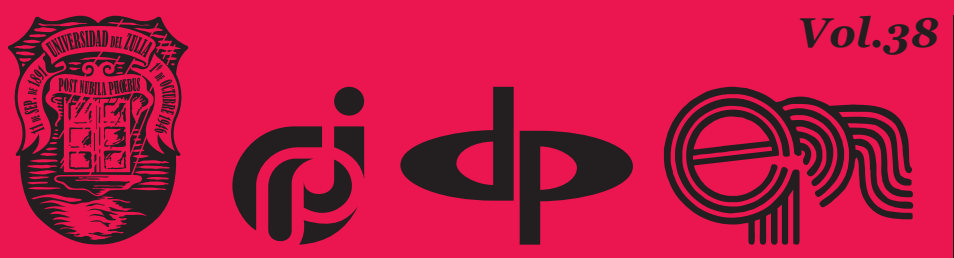

$N^{\circ}$ Especial 2da Parte 2020 


\title{
The investigator as an independent subject of criminal prosecution in cases of terrorist crimes
}

\author{
DOI: https://doi.org/10.46398/cuestpol.382e.25
}

\author{
Alexander Yurevich Epihin * \\ Oleg Aleksandrovich Zaitsev ** \\ Zyufyar Shakirovich Gataullin *** \\ Larisa Gennadyevna Tatyanina **** \\ Andrey Viktorovich Mishin *****
}

\section{Abstract}

This article aims to study the theory and practice of criminal prosecution of terrorist crimes in the Russian Federation. Most of the scientific work is mainly devoted to the study of criminal law and the criminological aspects of the fight against such criminal activities. It is therefore of particular importance to identify the problems of legal regulation of the investigator's activities in order to prosecute criminal offences and develop proposals for their optimal resolution. Cognitionic methods include: an anthropological, synthesis, statistics, partner, particular, systemic structural, legal modeling. In the Russian federation the prosecutor has judicial supervision in the criminal proceedings. Everything concludes that Federal Law of the Russian Federation No. 87-87-05.06.2007 redistributed control of the criminal proceedings by the investigator of the corporation a series of substantive rights of the chief prosecutor of the investigating body. In this sense, the optimal proportion of departmental control and tax supervision of the investigator, such as the establishment of a reasonable balance of these powers of control and supervision, increases the effectiveness of criminal prosecution of terrorism offences.

Key words: criminal prosecution; terrorism crimes; criminal prosecution in Russia; independent subject of criminal prosecution; effectiveness of criminal proceedings.

* Kazan Federal University, ORCID ID: https://orcid.org/oooo-0oo2-9514-5039. Email: doc@epihin. ru

** The Institute of Legislation and Comparative Law under the Government of the Russian Federation, https://orcid.org/oooo-ooo1-7185-9398. Email: ZaitsevA@mail.ru

*** Kazan Federal University, ORCID ID: https://orcid.org/oooo-0oo2-0435-408X. Email: ZSGataullin@ kpfu.ru

***** Udmurt state university. ORCID ID: https://orcid.org/oooo-0oo1-6404-6786. Email: TatyaninaLG@ mail.ru

******Kazan Federal University. ORCID ID: https://orcid.org/oooo-0002-4849-0710. Email: Andrey. Mishin@kpfu.ru 


\section{El investigador como sujeto independiente de enjuiciamiento penal en casos de crímenes terroristas}

\section{Resumen}

Este artículo tiene como objetivo estudiar la teoría y la práctica del enjuiciamiento penal de delitos terroristas en la Federación de Rusia. La mayor parte del trabajo científico se dedica principalmente al estudio del derecho penal y los aspectos criminológicos de la lucha contra este tipo de actividades delictivas. Por ello, es de especial relevancia identificar los problemas de regulación legal de las actividades del investigador con el fin de asegurar la efectiva persecución penal de los delitos terroristas y desarrollar propuestas para su óptima solución. Los métodos de cognición utilizados incluyen: análisis, síntesis, estadística, sociológico particular, estructural sistémico, modelado jurídico. En la federación rusa el fiscal ejerce la supervisión procesal en el proceso penal. Todo permite concluir que Ley Federal de la Federación de Rusia No. 87-Ф3, de fecha 05.06.2007, redistribuyó el control del proceso penal por parte del investigador porque transfirió una serie de derechos sustantivos del fiscal al jefe del órgano de investigación. En este sentido, la proporción óptima de control departamental y supervisión fiscal del investigador, así como el establecimiento de un equilibrio razonable de estos poderes de control y supervisión, aumentará la eficacia del procesamiento penal de los delitos de terrorismo.

Palabras clave: proceso penal; crímenes de terrorismos; persecución penal en Rusia; sujeto independiente de enjuiciamiento penal; eficacia del proceso penal.

\section{Introduction}

Terrorist crimes are a fairly common, as evidenced by statistics obtained from official sources. Thus, in 2015, the internal affairs bodies registered 1,538 crimes of a terrorist nature, in $2016-2,227$ crimes, in $2017-1,871$ crimes, in 2018 - 1,679 crimes, and in 2019 - 1,806 crimes (Official web-site of the ministry of internal affairs of the russian federation, 2014).

There is a slight increase in crime detection against the background of an increase in the number of recorded terrorist crimes: in 2015 detection was $37 \%$, in $2016-33 \%$, in $2017-45 \%$, in $2018-44.6 \%$, and in $2019-44.9 \%$. For comparison, the detection rate was $87.0 \%$ in 2007 (Official web-site of the ministry of internal affairs of the russian federation, 2014; Epikhin, 2016). 
Alexander Yurevich Epihin, Oleg Aleksandrovich Zaitsev, Zyufyar Shakirovich Gataullin, Larisa Gennadyevna Tatyanina y Andrey Viktorovich Mishin

Lack of effective scientific developments on the detection and investigation of such crimes (Vassalatiy, 2010) (this position is shared by those surveyed by us: $35.40 \%$ of prosecutors, $39.32 \%$ of investigators, $39.82 \%$ of judges), insufficient professional training of the law enforcement officers (the respondents showed solidarity with this position: $65.84 \%$ of prosecutors, $43.59 \%$ of investigators, $52.21 \%$ of judges) (Gataullin, 2015) are the main reasons for the negative statistics, for which not all criminal cases of terrorist crimes end in a trial.

The theorists take the side of practitioners on this issue and indicate the need to improve the level of legal culture of investigators, propose to review and tighten qualification requirements for the investigator candidates, note the importance of strengthening and optimizing personal responsibility, reviewing the criteria for evaluating investigative activities in their writings (Ogorodov, 2017). The discussion is raised by the problem of excluding terrorism cases from the jury's jurisdiction in Russian law (Yurevich Epihin et al., 2019).

\section{Methods}

The methods of cognition used include: analysis, synthesis, statistical, particular sociological, systemic structural, legal modeling and other methods.

\section{Results}

1. A decrease in the detection of terrorist crimes indicates a lack of professionalism and competence of investigators conducting investigative actions. In this regard, it is necessary to modify the conditions for their instruction and advanced training, as well as the requirements for staffing the investigative bodies with highly qualified employees.

2. By the adoption of the Federal Laws No. 87- $\Phi 3$ dated June 5, 2007 and No. 404- $\Phi 3$ dated December 28, 2010, the investigator's independence did not increase, the detection of crimes decreased, while the trend of growing violations of the law during investigative actions continued to grow.

3. Given the limited powers of the supervising prosecutor in pre-trial proceedings, it is difficult to count on increasing the effectiveness of criminal prosecution. 
4. It is proposed to return to the supervising prosecutor the procedural powers to guide the investigation, assigning the organization of investigative actions to the head of the investigative body.

\section{Discussion}

The requirements for professionalism and competence are indisputably the most important components that allow ensuring effective implementation of criminal prosecution by the investigator. At the same time, determination of greater independence in its procedural status is not less significant.

Investigations of the problems of the investigator's procedural independence in criminal proceedings provoke heated debates among processors. To this day, they continue to remain in the spotlight. Thus, S.N. Khoryakov believes that the investigator's activities are not possible without procedural independence (Khoryakov, 2006). N.I. Kulagin considers the status of the investigator's independence as an important component for the full protection of the interests of crime victims (Kulagin, 1995). According to A.R. Vartanov, the procedural independence of the investigator is necessary to achieve the goal of criminal proceedings (Vartanov, 2012).

Of course, each of these positions deserves attention. Providing the investigator with procedural independence is not in doubt, but the legislator's attempt to isolate the investigator from the permanent custody of the supervising prosecutor by adopting the Federal Law No. 87- $\Phi 3$ dated June 5, 2007 was not entirely successful (Malysheva, 2009).

Based on the changes made to the Criminal Procedure Code of the Russian Federation (Balakshin, 2011), the investigator's independence was more infringed, because the investigator's right to direct the investigation was substantially limited by the need to coordinate many of his decisions with the head of the investigative body. At present, a paradoxical situation has developed: on the one hand, the legislator's efforts have limited the procedural powers of the supervising prosecutor, on the other hand, the problem of the procedural independence of the investigator has not been resolved (Bykov, 2008).

The reforms initiated on the basis of the Law No. 87- $\Phi 3$ were aimed at increasing the effectiveness of the preliminary investigation, improving the disclosure, while strictly complying with the legislation requirements. However, the expected increase in the level of crime detection was not achieved. Thus, the detection of terrorist crimes has a downward tendency since 2007. If their disclosure amounted to $87.0 \%$ in 2007 , then it decreased 
Alexander Yurevich Epihin, Oleg Aleksandrovich Zaitsev, Zyufyar Shakirovich Gataullin, Larisa Gennadyevna Tatyanina y Andrey Viktorovich Mishin

to $85.7 \%$ in $2008,81.0 \%$ - in $2009,70.5 \%$ - in $2010,68.8 \%$ - in $2011,75.0 \%$ - in 2012, 69.0\% - in 2013, etc., then it was $44.9 \%$ in 2019.

Violations of the law during the investigative actions have not decreased. They tend to increase. Thus, the Prosecutor General's Office of Russia sent 215,246 claims to eliminate violations in 2015, while the number of such claims increased to 316,820 in 2019 (Official web-site of the general prosecutor's office of the russian federation, 2018).

Consequently, with the enactment of the Law No. 87-Ф3, the investigator's independence did not increase, on the one hand, but the deprivation of the supervising prosecutor of the procedural powers and the transfer of these powers to the head of the investigative body led to a decrease in the detection of crimes and a significant increase in violations of the law during the investigative actions, on the other hand.

As a result of the reform, independence was not acquired by the investigators, but by their heads. The investigator became virtually dependent on the head of the investigative body, endowed with the procedural, administrative and disciplinary powers by the legislator.

The Russian legislator, seeking to further increase the status of the head of the investigative body by the Law No. 404- $\Phi 3$, gave him new additional powers, in particular, the right to cancel the decision not only of the investigator, but also of the head of even another investigative body, which is not directly subordinate to it, nor in the procedural, neither in the administrative relations.

We think that it is possible to grant the investigator the status of independence, provided that his head is deprived of broad powers to coordinate current investigator's decisions, while retaining his authority to organize an investigation of crimes. The investigator's independence does not mean the absence of control and supervision over his activities. Participation in the pre-trial proceedings by the prosecutor and the court is a reliable guarantee of ensuring the supervisory and control functions necessary, first of all, for observing the individual's rights in the criminal proceedings.

The procedural activities of such high-level participants in the criminal proceedings as investigator and prosecutor should be aimed at establishing the truth, with strict observance of the legislation requirements. It seems important to note the independent direction of the investigator's procedural activity - ensuring the participants' safety in the pre-trial criminal proceedings (Epikhin et al, 2016). And he should take timely and sufficient measures aimed at the safe participation in certain investigative and other actions. Measures of criminal procedural security are set in Part 3 of Art. 11 of the Criminal Procedure Code of the Russian Federation (interrogation under a pseudonym; control and recording of negotiations; identification 
outside visual control; closed court session and interrogation in court without disclosing true data).

In our opinion, particular attention should be given to improving the tactics of investigative actions involving the use of criminal procedural security measures.

In addition, the investigator's arsenal has a set of measures established in the Federal Law No. 119-3 dated April 20, 2004 "On State Protection of Victims, Witnesses and other Participants in the Criminal Proceedings" (Fletcher, 2006). When ensuring the safety of proceedings, it is very relevant to carry out constructive interaction of the investigator with the authorities engaged in the operational-search activities, including units charged with the implementation of such state protection measures as relocation to a new place of residence, work or study; replacement of documents, etc.

In recent decades, terrorism has acquired a transnational character and various, including criminal, forms of expression. In this regard, in order to successfully investigate terrorist crimes, the investigator's activities, in our opinion, should be carried out at a new procedural level. In particular, the definition of the legal mechanism for the creation and procedural activities of joint international investigative and investigative-operational groups is of particular importance. From the standpoint of the activity tactics of such groups, it is important to develop a certain procedure for the participation of investigators, operational officers and representatives of other law enforcement agencies in their composition.

Almost significant should be considered a study of the peculiarities of legislative regulation of criminalistical support for investigation of terrorist crimes as part of an international investigation group.

\section{Summary}

As a result of the study, we can make the following conclusions:

1. The continued growth tendency of terrorist crimes (from 1,127 in 2014 to 1,679 in 2018) indicates that there are problems ensuring adoption of preventive measures by the law enforcement agencies to prevent or minimize the commission of terrorist crimes.

2. Based on the analysis of downward tendency in the detection of terrorist crimes (from $51 \%$ in 2014 to $44.6 \%$ in 2108 ), it follows that there are problems in the procedural activities of the investigating authorities, including insufficient professional training of the law enforcement officers. 


\section{Alexander Yurevich Epihin, Oleg Aleksandrovich Zaitsev, Zyufyar Shakirovich Gataullin, Larisa Gennadyevna Tatyanina y Andrey Viktorovich Mishin

3. The legislator's aspirations to free the investigator from the procedural custody of the supervising prosecutor and to give the investigator independence status by adopting the Federal Law No. 87- $\Phi 3$ dated June 5, 2007 did not lead to the expected result. Procedural independence is necessary for the investigator to achieve the ultimate goal of criminal proceedings, to establish the truth on the basis of legality, validity and justice.

The research results of this article can be applied to continue research on the development of theoretical provisions in order to further develop the criminal procedure science.

The practical significance of the results is expressed in the possibility of using them in the criminal prosecution of terrorist crimes.

The social significance of the results is to protect the rights of citizens participating in the criminal proceedings in cases of terrorist crimes, including consideration and resolution of claims against illegal actions of the investigator.

The value of the results is due to the presence of identified problematic aspects of a theoretical and practical nature aimed at improving the effectiveness of criminal prosecution of terrorist crimes carried out by the investigator. Based on the study, we obtained new knowledge and recommendations aimed at improving the quality of investigative actions, and the findings can be useful to minimize the commission of terrorist crimes and increase their detection.

\section{Conclusions}

Thus, legal regulation of the investigator's procedural independence as an active participant in the criminal prosecution of terrorist crimes should be aimed at establishing the optimal balance of prosecutorial supervision and departmental control by the head of the investigative body for the criminal case.

An integral element of the criminal prosecution in this category of criminal cases should be the maintenance of an adequate security level for its participants.

Increase in the effectiveness of the criminal prosecution of the crimes under consideration is largely achieved through the constant interaction of the investigator with the operational officers, specialists, experts as part of the investigative-operational groups. 


\section{Acknowledgements}

The work is performed according to the Russian Government Program of Competitive Growth of Kazan Federal University.

\section{Bibliographic References}

BAILEY, Alison; CREE, Lisa. 2011. "Terrorism preparation by Michigan law enforcement agencies" In: American journal of criminal justice. Vol. 36, No. 4, pp. 434-447.

BALAKSHIN, Villar. 2011. “Independent - dependent investigator” In: Legality. Vol. 10, pp. 29-34.

BYKOV, Vyacheslav. 2008. "Investigator's procedural independence" In: Criminal process. Vol. 5, pp. 40-43.

EPIKHIN, Alexander. 2016. "Protection by the government and security support for the parties of modern criminal process in Russia: Problems and perspectives" In: Journal of Legal, Ethical and Regulatory. Vol. 19.

EPIKHIN, Alexander; MAKEEVA, Inna; TASAKOV, Sergei; MISHIN, Andrei; SLED, Yurii; ZEINALOVA, Larisa. 2016. "Protection of the Witnesses and Victims: International Legal Acts, Legislation of some States and the Modern Russian Legislation” In: Journal of Advanced Research in Law and Economics. Vol. 7, No. 2, pp. 313-322.

FLETCHER, George. 2006. “The Indefinable Concept of Terrorism” In: Journal of International Criminal Justice. Vol. 4. No. 5, pp. 894- 911.

GATAULLIN, Zyufyar Shakirovich. 2015. Theoretical and procedural aspects of the prosecution of terrorism cases: monograph. Publishing House of the Elabuga Institute of the K(V)FU. Elabuga, Russia.

KHORYAKOV, Sergey. 2006. Investigator's procedural independence: thesis for the Candidate of Law. Chelyabinsk, Russia.

KULAGIN, Natlali. 1995. In defense of the rights and legitimate interests of the investigator. Human rights and law enforcement. Volgograd, Russia.

LABORDE, Jean-Paul; DEFEO, Michael. 2006. "Problems and prospects of implementing UN action against terrorism" In: Journal of International Criminal Justice. Vol. 4, No. 5, pp. 1087-1103. 
Alexander Yurevich Epihin, Oleg Aleksandrovich Zaitsev, Zyufyar Shakirovich Gataullin, Larisa Gennadyevna Tatyanina y Andrey Viktorovich Mishin

MALYSHEVA, Olga A. 2009. "The procedural position of the investigator in the conditions of modern legal regulation" In: Russian investigator. Vol. 2, pp. 8-10.

OFFICIAL WEB-SITE OF THE GENERAL PROSECUTOR'S OFFICE OF THE RUSSIAN FEDERATION. 2018. Available online. In: http:// genproc.gov.ru/upload/iblock/6f3/0112_2018.xls. Consultation date: 15/05/2020.

OFFICIAL WEB-SITE OF THE MINISTRY OF INTERNAL AFFAIRS OF THE RUSSIAN FEDERATION. 2014. Available online. In: http://www.mvd. ru. Consultation date: 15/05/2020.

OGORODOV, Andre. 2017. Investigator's procedural independence in criminal proceedings: thesis for the Candidate of Law. Chelyabinsk, Russia.

VARTANOV, Alexander. 2012. Problems of the investigator's procedural independence under the Criminal Procedure Code of the Russian Federation: abstract of a thesis for the Candidate of Law. Krasnodar, Russia.

VASSALATIY, Zhander. 2010. Methods of investigating crimes of a terrorist nature: abstract of a thesis for the Candidate of Law. Chelyabinsk, Russia.

YUREVICH, Alexander Epihin; GATAULLIN, Zyufyar Shakirovich; ZAITSEV, Oleg Aleksandrovich; GRISHINA, Ekaterina Pavlovna; MISHIN Andrey Viktorovich. 2019. "Criminal prosecution of terrorist crimes in jury trial: legality and appropriateness" In: Humanities \& Social Sciences Reviews. Vol. 7, No. 5, pp. 674-677. 

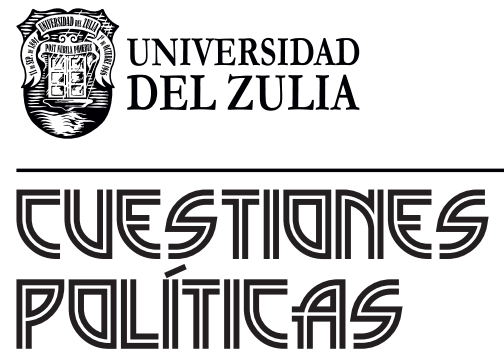

Vol.38 NEspecial

Esta revista fue editada en formato digital y publicada en diciembre de 2020, por el Fondo Editorial Serbiluz, Universidad del Zulia. Maracaibo-Venezuela 